\title{
Construction of Evaluating Index System for Management Modernization of Agricultural Water Engineering
}

\author{
Yuan-Ping $\mathrm{CAO}^{1, \mathrm{a}}$ and Ying SONG, ${ }^{2, \mathrm{~b},}$ \\ ${ }^{1}$ School of Business, Wuzhou University, P.R.China \\ a'Email : 1113594073@qq.com, bemail : 362612807@qq.com \\ ${ }^{*}$ Corresponding author
}

Keywords: agricultural water engineering, management modernization, evaluation index, evaluation index system

\begin{abstract}
In order to reflect thoroughly and objectively the developing level of management modernization of agricultural water engineering, put forward "nine index system" from Chinese conditions and the practice of water engineering. Classify the index system from qualitative and quantitative analysis, define the weight and criteria, and then construct comprehensive evaluating project.
\end{abstract}

\section{Introduction}

The management modernization of agricultural water engineering is an important factor to achieve modernization of the State. Its connotation is rich, which not only relates to social economy and ecological effect, but includes the evaluation of water environment, management mechanism and methods and managing talents. The scientific evaluating index system and evaluating method is essential to evaluate modernization level. Scholars evaluate management modernization of water engineering from various perspectives qualitatively and quantitatively ${ }^{[1]}$. For improving the managing level and providing theoretical foundation to agricultural modernization, combined with theory and practice, this paper sets up the managing and evaluating index system, which could provide reference and foundation for agricultural water engineering management.

\section{The Connotation of Management Modernization of Agricultural Water Engineering}

Management modernization of agricultural water engineering is key to country's modernization, and critical to water engineering and agricultural engineering dynamic management. From the current engineering situation, the connotation includes constructing water engineering management system in advance and scientificly adapted to agricultural developing, such as, high standard to agricultural hydraulic engineering, advanced monitoring and scheduling system and adapting management pattern. Based on the theory of market economic system, scientific outlook on development and countryside developing strategy, the management could be institutionalization, standardization and scientification, and then achieve modernization for agriculture and water and ecological sustainability.

\section{Principles to Management Modernization of Agricultural Water Engineering[2]}

In order to reflect the developing level of different regional construction objectively and thoroughly, it should be went by the following principles. (1)goal-directed: meet the requirements and goals of agricultural water engineering; (2) system's advanced and coordinated possibility;(3) not only reflect managing level, but display the effect as well; (4)to fulfill combination of quantitative and qualitative index; (5) consider completely practical and typical; (6) to combine with hierarchy and comparability, that is, each index at the same hierarchy could be compared; (7) to combine with dynamic and static. 


\subsection{Index system [3]}

According to the researches, following well-established evaluating index system at home and abroad, construct "nine index system", including (1) management mechanism level rationally ; (2) standardized level of management; (3) dispatch level automatically and informationization; (4) managing level of safety of engineering operating; (5) performance level of engineering operating; (6) good level of facilities and theirs function; (7) legal environment; (8) water Eco-environment protection; (9) technology of human resource. Followed by principles, take these as the first-class index, and then branch out the second.

\subsection{Index system frame}

\subsubsection{Qualitative index}

The data uncertain and unstable could be seen as qualitative index as well as human factors.

Table 1 Qualitative Index of Management Modernization of Agricultural Water Engineering

\begin{tabular}{|c|c|c|c|}
\hline \multicolumn{2}{|c|}{$\begin{array}{l}\text { the first-class index } \\
\left(\mathrm{W}_{\mathrm{i}}\right)\end{array}$} & \multicolumn{2}{|l|}{ the second-class index $\left(\mathrm{W}_{\mathrm{iJ}}\right)$} \\
\hline $\begin{array}{l}\text { 1. management } \\
\text { mechanism level } \\
\text { rationally }\left(\mathrm{W}_{1}\right)\end{array}$ & $\mathrm{A}_{1}$ & $\begin{array}{l}\text { (1)clarification of water management correctly and rationally; } \\
\text { (2)separating plan of management and maintain, operation; } \\
\text { (3)available fee of managing and maintaining; } \\
\text { (4)advanced management mechanism }\end{array}$ & $\begin{array}{l}\mathrm{A}_{11} \\
\mathrm{~A}_{12} \\
\mathrm{~A}_{13} \\
\mathrm{~A}_{14}\end{array}$ \\
\hline $\begin{array}{l}\text { 2. standardized } \\
\text { level of } \\
\text { management }\left(\mathrm{W}_{2}\right)\end{array}$ & $\mathrm{A}_{2}$ & $\begin{array}{l}\text { (1)engineering safety, perfect monitoring system and normalized } \\
\text { operation; } \\
\text { (2)perfect and normalized management system of engineering } \\
\text { maintenance plan; } \\
\text { (3)the operation of engineering controlling plan and operating } \\
\text { system; } \\
\text { (4)the perfection of pre-arranged plannings of water engineering; } \\
\text { (5)the perfection of rules and regulations and system of personal } \\
\text { responsibility; } \\
\text { (6)the perfection of talent development scheme and incentive } \\
\text { mechanism of technology innovation. }\end{array}$ & $\begin{array}{l}\mathrm{A}_{21} \\
\mathrm{~A}_{22} \\
\mathrm{~A}_{23} \\
\mathrm{~A}_{24} \\
\mathrm{~A}_{25} \\
\mathrm{~A}_{26}\end{array}$ \\
\hline $\begin{array}{l}\text { 3. dispatch level } \\
\text { automatically and } \\
\text { informationization } \\
\left(\mathrm{W}_{3}\right)\end{array}$ & $\mathrm{A}_{3}$ & $\begin{array}{l}\text { (1)the informationization of water engineering management; } \\
\text { (2)the advanced automatic system of the safeguard of water } \\
\text { engineering; } \\
\text { (3)the advanced automatic monitor system of Sluice Gate Station. } \\
\text { (4)the advanced dispatching system of regime prediction and } \\
\text { water engineering operation. }\end{array}$ & $\begin{array}{l}A_{31} \\
A_{32} \\
A_{33} \\
A_{34}\end{array}$ \\
\hline $\begin{array}{l}\text { 4. managing level } \\
\text { of safety of } \\
\text { engineering } \\
\text { operating }\left(\mathrm{W}_{4}\right)\end{array}$ & $\mathrm{A}_{4}$ & $\begin{array}{l}\text { (1)the perfection of anti-accident plan of water engineering; } \\
\text { (2)the perfection of reporting system; } \\
\text { (3)the implementation of responsibility. }\end{array}$ & $\begin{array}{l}\mathrm{A}_{41} \\
\mathrm{~A}_{42} \\
\mathrm{~A}_{43}\end{array}$ \\
\hline $\begin{array}{l}\text { 5. legal } \\
\text { environment } \\
\left(\mathrm{W}_{5}\right)\end{array}$ & $\mathrm{A}_{5}$ & $\begin{array}{l}\text { (1)the completion of demarcation of managing confine; } \\
\text { (2)the perfection of legal management; } \\
\text { (3)the improvement of quality of water administration and } \\
\text { supervisory personnel; } \\
\text { (4)the involvement of public. }\end{array}$ & $\begin{array}{l}A_{51} \\
A_{52} \\
A_{53} \\
A_{54}\end{array}$ \\
\hline
\end{tabular}




\subsubsection{Quantitative index}

The data that is certain and smaller human factors could be seen as quantitative index .

Table 2 Quantitative Index of Management Modernization of Agricultural Water Engineering

\begin{tabular}{|c|c|c|c|}
\hline \multicolumn{2}{|c|}{$\begin{array}{l}\text { the first-class index } \\
\left(\mathrm{W}_{\mathrm{i}}\right)\end{array}$} & \multicolumn{2}{|l|}{ the second-class index $\left(\mathrm{W}_{\mathrm{iJ}}\right)$} \\
\hline $\begin{array}{l}\text { 1. performance } \\
\text { level of } \\
\text { engineering } \\
\text { operating }\left(\mathrm{W}_{6}\right)\end{array}$ & $\mathrm{B}_{1}$ & $\begin{array}{l}\text { (1)the perfection of engineering facilities; } \\
\text { (2)the success rate of engineering design }\end{array}$ & $\begin{array}{l}\mathrm{B}_{11} \\
\mathrm{~B}_{12}\end{array}$ \\
\hline $\begin{array}{l}\text { 2. good level of } \\
\text { facilities and } \\
\text { theirs function } \\
\left(\mathrm{W}_{7}\right)\end{array}$ & $\mathrm{B}_{2}$ & $\begin{array}{l}\text { (1)cleaning; } \\
\text { (2)greenery coverage; } \\
\text { (3)improvement rate of soil and water loss; } \\
\text { (4)ratio up to the standard of water quality of water domain }\end{array}$ & $\begin{array}{l}\mathrm{B}_{21} \\
\mathrm{~B}_{22} \\
\mathrm{~B}_{23} \\
\mathrm{~B}_{24}\end{array}$ \\
\hline $\begin{array}{l}\text { 3. water } \\
\text { Eco-environment } \\
\text { protection }\left(\mathrm{W}_{8}\right)\end{array}$ & $\mathrm{B}_{3}$ & $\begin{array}{l}\text { (1)levying rate of water fee and others; } \\
\text { (2)utilization ratio of available land resource; } \\
\text { (3)profit-loss ratio of operating items of water management. }\end{array}$ & $\begin{array}{l}\mathrm{B}_{31} \\
\mathrm{~B}_{32} \\
\mathrm{~B}_{33}\end{array}$ \\
\hline $\begin{array}{l}\text { 4. technology of } \\
\text { human resource } \\
\left(\mathrm{W}_{9}\right)\end{array}$ & $\mathrm{B}_{4}$ & $\begin{array}{l}\text { (1)the technological quality of persons at work, structure and } \\
\text { adaptation ; } \\
\text { (2)the ration of persons with college or above. }\end{array}$ & $\begin{array}{l}\mathrm{B}_{41} \\
\mathrm{~B}_{42}\end{array}$ \\
\hline
\end{tabular}

\subsubsection{Define the weight of index}

Defining the weight is a key step to multi-index comprehensive evaluation. Reasonable and correct weight affects directly the reliability of result. There are two ways to define index weight.

Delphi method can be applied to set up the index system, and given weight to index ${ }^{[4]}$. Delphi method is also known as method of specialist investigation, which is a way to collect specialists' advice without meeting and can make full use of their knowledge and experience. Firstly, design questionnaire. Then invite experts from the authorities of agricultural and water conservancy and basic unit of water. They give advice to evaluation index system and weights to index according to their own experience. During the first consulting, based on AHP, experts give advice on relative importance of evaluation index. Synthesize these expert's opinion and construct matrix, and then conduct consistency checking. Next, consult experts' advice again, making these close to a convergence, summarize and process these feedback and define weights.

Using AHP to define index weight is another way ${ }^{[5]}$. Monitor the actual value of quantitative index combine conditions of agricultural water engineering. The weights can be defined by AHP.

(1)Introduce collection $I=\left\{I_{1}, I_{2}, \ldots, I_{i}, \ldots, I_{n}\right\}$ as factors evaluation set. To $I$, experts conduct comparative analysis pairwise, and under the rule (shown by table 3 ), quantitative analysis, using the scaling procedure, is made regarding relative importance of any two ways, which bring up constructing fuzzy judgment matrix $R=\left(a_{i j}\right) n \times n$

$$
\begin{aligned}
& a_{i i}=0.5 ;(\mathrm{i}=1,2, \ldots, \mathrm{n}), \\
& a_{i j}+a_{i j}=1 ;(\mathrm{i}, \mathrm{j}=1,2, \ldots, \mathrm{n})
\end{aligned}
$$

$a_{i i}$ is diagonal element. When its value equals 0.5 , means the same importance of two; $a_{i j}>0.5$ means that $I_{i}$ is more important than $I_{j} ; \quad a_{i j}<0.5 \quad I_{j}$ is more important than $I_{i}$. 
Table 3 rule of judgement matrix scale

\begin{tabular}{|c|c|c|}
\hline scale & definition & Connotation \\
\hline 0.5 & the same important & the same contribution of two index \\
\hline 0.6 & more important & $\begin{array}{l}\text { lean towards judgement and experience } \\
\text { indexes }\end{array}$ \\
\hline 0.7 & obvious important & $\begin{array}{l}\text { lean obviously to judgement and } \\
\text { experience indexes }\end{array}$ \\
\hline 0.8 & very important & lean heavily to one index \\
\hline 0.9 & $\begin{array}{l}\text { extremely } \\
\text { important }\end{array}$ & lean extremely to one index \\
\hline $0.1-0.4$ & complementation & the judgement of two $a_{i j}=1-a_{i j}$ \\
\hline
\end{tabular}

(2)Combined with fuzzy theory and the above judgement rule, construct Complementary judgement matrices as follows.

$$
R=\left[\begin{array}{cccc}
a_{11} & a_{12} & \cdots & a_{1 n} \\
a_{21} & a_{22} & \cdots & a_{2 n} \\
\vdots & \vdots & \vdots & \vdots \\
a_{n 1} & a_{n 2} & \cdots & a_{n n}
\end{array}\right]
$$

The judgement matrix that has more uniformity bias affect directly on reliability and accuracy of result, and there is uncertain for taking this matrix as decision support. So it is essential to make consistency checking. Define Complementary judgement matrices $R=\left(a_{i j}\right) n \times n$, which comply with consistency checking.

$$
a_{i j}=a_{i k}-a_{j k}+0.5 ; \quad(\mathrm{i}, \mathrm{j}=1,2, \ldots, \mathrm{n})
$$

If matrix $R=\left(a_{i j}\right) n \times n$ is not in accordance with consistency checking, it should be conversed as follows.

$$
a^{*}=\frac{1}{n}\left(\sum_{r=1}^{n} a_{i r}-\sum_{r=1}^{n} a_{j r}\right)+0.5 ; \quad(\mathrm{i}, \mathrm{j}, \mathrm{r}=1,2, \ldots, \mathrm{n})
$$

Construct $R^{*}=\left(a_{i j}{ }_{i j}\right) n \times n$,conforming to the consistency checking. The fuzzy judgement matrix could be calculated as follows.

$$
w_{i}=\left[\frac{n}{2}+\sum_{j=1}^{n} a_{i j}-1\right] /[n(n-1)]
$$

Then find the solution and calculate the assigned weight vector of factors evaluation set I, according to the above and the following formula .

$$
w_{i}=\left(\prod_{p=1}^{m} w_{i}^{(p)}\right)^{m / 2} ; \quad(\mathrm{i}=1,2, \ldots, \mathrm{m})
$$

According to normalized standard, normalize the assigned weight vector as formula(7), and then achieve proper vector of the optimal plan step by step. $w_{i}=\left(w_{1}, w_{2}, \ldots, w_{9}\right)^{T}$

$$
w_{i}=w_{i}^{0} / \sum_{i=1}^{n} w_{i}^{o}
$$

\subsection{Evaluation method}

\subsubsection{Qualitative index evaluation}

Based on the situation, according to five evaluation standard, that is, excellent, good, moderate, qualified, unqualified, the realization degree of modernization could be classified five classification A, B, C, D, E, and values respectively are A $(0.9-1.0)$, B (0.8-0.89) , C (0.7-0.79) , D ( 0.6 $-0.69), \mathrm{E}(0.0-0.59)$. 


\subsubsection{Quantitative index evaluation}

Combined with the practice and the connotation of quantitative index as well as experts' experience, construct judgement matrix according to AHP. Define weights and realization degree, evaluate modernization and calculate quantitative value.

\subsubsection{Comprehensive evaluation}

Each index belongs to different membership, solve and construct the jud gement matrix. Obtain the comprehensive evaluation result according to $\mathbf{X}_{\mathbf{i}}=\mathbf{W}_{\mathbf{i}} \times \mathbf{R}$, shown by table 4 .

Table 4 Evaluation Results of Management Modernization of Agricultural Water Engineering

\begin{tabular}{cccc}
\hline $\begin{array}{c}\text { kind of } \\
\text { index }\end{array}$ & $\begin{array}{c}\text { the first-class } \\
\text { index }\end{array}$ & $\begin{array}{c}\text { Weight(evaluat } \\
\text { ion) }\end{array}$ & Realization degree/\% \\
\hline quality & $\mathrm{A}_{1}$ & $\mathrm{~W}_{1}$ & $\mathrm{X}_{1}$ \\
& $\mathrm{~A}_{2}$ & $\mathrm{~W}_{2}$ & $\mathrm{X}_{2}$ \\
& $\mathrm{~A}_{3}$ & $\mathrm{~W}_{3}$ & $\mathrm{X}_{3}$ \\
& $\mathrm{~A}_{4}$ & $\mathrm{~W}_{4}$ & $\mathrm{X}_{4}$ \\
& $\mathrm{~A}_{5}$ & $\mathrm{~W}_{5}$ & $\mathrm{X}_{5}$ \\
& $\mathrm{~B}_{1}$ & $\mathrm{~W}_{6}$ & $\mathrm{X}_{6}$ \\
& $\mathrm{~B}_{2}$ & $\mathrm{~W}_{7}$ & $\mathrm{X}_{7}$ \\
& $\mathrm{~B}_{3}$ & $\mathrm{~W}_{8}$ & $\mathrm{X}_{8}$ \\
& $\mathrm{~B}_{4}$ & $\mathrm{~W}_{9}$ & $\mathrm{X}_{9}$ \\
\hline
\end{tabular}

\subsection{Evaluation rules [2]}

It could develop evaluation rules from three aspects. Firstly, initial realization, which reaches above $85 \%$. Secondly, approximate realization, which above. The third, comprehensive realization, which is above $95 \%$, At the same time, the second-class index also conform to table 5 .

Table 5 Evaluation Rules of Management Modernization of Agricultural Water Engineering.

\begin{tabular}{c|ccc}
\hline \multirow{2}{*}{ construction phase } & \multicolumn{3}{|c}{ judging standard $(\mathrm{X} \%)$} \\
\cline { 2 - 4 } & $\begin{array}{c}\text { Comprehensive } \\
\text { evaluation }\end{array}$ & $\begin{array}{c}\text { the first-class index } \\
\text { system }\end{array}$ & $\begin{array}{c}\text { the second-class } \\
\text { index system }\end{array}$ \\
\hline $\begin{array}{c}\text { initial modernization } \\
\text { approximate } \\
\text { modernization } \\
\begin{array}{c}\text { comprehensive } \\
\text { modernization }\end{array}\end{array}$ & $\begin{array}{c}\text { above } 85 \% \\
\text { above } 90 \%\end{array}$ & $\begin{array}{c}\text { above } 85 \% \\
\text { above } 90 \%\end{array}$ & $\begin{array}{c}\text { above } 80 \% \\
\text { above } 85 \%\end{array}$ \\
\hline
\end{tabular}

\section{Conclusion [5]}

The management of agricultural water engineering is changing, periodically and regularly. It should improve fully water infrastructure and management .

(1) Insist on government-dominant model and input in advance, multi-chanel financing supports constructing infrastructure. Further increase the government investment at all levels and social funds.

(2) Insist on problem-oriented and plan in advance, prompt irrigation engineering of " the last kilometre". there are many problem to finish highly "the last kilometre", including poorly infrastructure, low standard, and short of investment. It should be improved based on problem-oriented.

(3) place an emphasis on cooperative capability of government and peasant to manage and maintain water engineering. Clear property right further and rationalize mechanism.

(4) Lay equal stress on construction and management. Through deepening the reform in 
management of small irrigation system, including define engineering property right, make clear the management, innovate managing and maintaining pattern.

Management modernization of agricultural water engineering is a stage dynamically, reflecting the feature of regional economic developing. There are many factors that have impact on management. So it is important to improve further the evaluation index system.

\section{Acknowledgment}

This research was financially supported by College-level key research project “ Study on Agricultural Sustainability of Zhujiang-Xijiang Economic Belt” (No. 2018B004).

\section{References}

[1] S. Lijuan, Study on Water Conservancy Project Management Modernization and Its Evaluation Index System. Heilongjiang Science and Technology of Water Conservancy. 10(2018)180-183 (in Chinese).

[2] F. Guohua, G. Yuqin, T. Weixiong, Z. Zaizhou, G. Ning, Establishment of Evaluation Index System for Modernization of Water Conservancy Project Management, Advances in Science and Technology of Water Resource. 3(2012)39-43 (in Chinese).

[3] Ou Y. Hongxiang, L. Xin, F. Guohua, Research on the Management Modernization and Evaluation Index System of Hydraulic Projects, South-to-North Water Diversion and Water Science \&Technology. 1(2012)150-152(in Chinese).

[4] Aminagu.Study on Evaluation Index System of Regional Water Conservancy Modernization, Heilongjiang Science and Technology of Water Conservancy. 7(2018) 233-236(in Chinese).

[5] L. Ruifang, Situation Analysis and Countermeasures of Agricultural Water Engineering Management., Shaanxi Water Resource. 5(2019):189-190 (in Chinese). 